\title{
Genetic Identification of Some Guava Seedling Trees
}

\author{
${ }^{1}$ Sharaf, M. M., ${ }^{1}$ Khamis, M.A, ${ }^{1}$ Bakry, KH. A., ${ }^{2}$ Saaed W.T and ${ }^{2}$ EL-Tarawy, O.M. \\ ${ }^{1}$ Hort. Dept. Fac. of Agric. Benha Univ. Egypt. \\ ${ }^{2}$ Hort. Res. Inst., Giza, Egypt. \\ Corresponding author: osamaaltarawy@gmail.com
}

\begin{abstract}
This research was conducted in two main techniques: The first was Molecular genetic identification for twelve guava seedling trees. RAPD and ISSR based on PCR techniques five primers were used had successfully generated reproducible polymorphic products to study the genetic variability between the twelve guava seedling trees. Data cleared that, a total bands of guava seedling trees with RAPD - ISSR primers were recorded 94 band where the total polymorphic bands was recorded 48 with polymorphic percentage $51.06 \%$. While, combining RAPD and ISSR, construct classify twelve guava seedling trees. Results from this analysis showed two main groups. The first main group was between seedling trees 9 and 12 and the second main group was divided into two sub main groups: the first sub main group included genotype 1 alone and the second sub main group was divided into two sub sub group which included the remained seedling trees. The second was: Protein electrophoresis analysis for the twelve guava seedling trees revealed a total number of 16 bands eight of them were polymorphic with 50\% polymorphism. While, peroxidase and polyphenyl Oxidase analysis for the twelve guava seedling trees, all of bands illustrated were characterized for all the guava seedling trees studied, which all of them (monomorphic) with differences in their banding patterns densities
\end{abstract}

Keywords: Guava seedling trees, Psidium guajava, RAPD and ISSR.

\section{Introduction}

Guava "Psidium guajava, Linn." Is the most important fruit species of the family "Myrtaceae". Guava fruits are delicious, rich in vitamin ' $\mathrm{C}$ ', carotene, thiamine, antioxidants, pectin and minerals like calcium, phosphorus and iron. Guava fruits are consumed as fresh fruits and industrial as jam, jelly, nectar etc. (Boora, 2012). It is believed to be native to the area between Mexico and Peru, from where it has spread to almost all (Chandler, 1958).

As for horticulturists, guava is admired as being of low cultural requirements. For instance, the trees are successfully grown on various kinds of soils, rich or poor; dry or moist (Popenoe, 1988).

In Egypt, the total cultivated area of guava trees reached about 37398 Feddan and fruiting orchards about 33512 Feddan that producing about 307535 tons. (Anonymous, 2019).

Identification of plant has usually been carried out by morphological and agronomical characteristics. The environment often influences these characters. Therefore it is advisable to use alternative methods, which are less affected by the environment. Several modern techniques such as RAPD, ISSR, SDS protein, isozyme analysis...etc., are being used for more effective means of identification of the diversity within many fruit trees such as guava (Hassan et al., 1998 and Tijet et al., 2000), citrus (Cabrita et al., 2001), olives ( Cresti et al., 1997).

When comparing several methods, such as SDS protein patterns, isozyme indices, and RAPD analysis, it was found that SDS pattern or isozyme indices did not stand alone to provide sufficient polymorphic expressions to distinguish between guava cultivars in a unique pattern. On the other hand, RAPD analysis proved to be more powerful in discriminating between the studied guava cultivars (Hassan et al., 1998).

Accordingly, the present study aimed to throw some lights on some techniques of finger printing analysis and determining whether is more informative one in assessment of the genetic similarity and diversity in such selected genotypes (seedling trees).

\section{Materials and Methods}

Finger printing analysis: Finger printing analysis techniques for studying the genetic diversity of the twelve selected guava seedling trees (genotypes).

\section{Leaf protein and isozyme electrophoreses:}

SDS-polyacrylamide gel electrophoresis was performed in $12 \%$ acrylamide slab gels following the system of Laemmli (1970) to identify their protein profiles. Fresh and young leave samples for each strain and location were used separately for isozymes extraction. The utilized isozymes are Peroxidase (Px), Polyphenyl Oxidase (PPO) Protein extraction was conducted by mixing $0.2 \mathrm{~g}$ of young leaves of guava with an equal weight of pure, clean, sterile fine sand. The samples then ground to fine powder using a mortar and pestle and homogenized with $1 \mathrm{M}$ Tris$\mathrm{HCl}$ buffer, $\mathrm{pH} 6.8$ in clean eppendorf tube and left in refrigerator overnight. Then centrifuged at $10.000 \mathrm{rpm}$ for $10 \mathrm{~min}$. The supernatant of each sample (contains protein extract) was kept in deep-freeze until use for electrophoretic analysis. Then boil for 5 minutes in water bath before loading in the gel. Nativepolyacrylamide gel electrophoresis (Native-PAGE) was conducted to identify isozyme variations among 
studied strains using three isozyme systems according to Stegemann et al. (1985).

PCR analysis based on RAPD and ISSR polymorphism.

DNA was extracted from young leaves of guava plants by Cetyltrimethyl Ammonium Bromide
(CTAB) according to Doyle and Doyle (1990). The DNA amplifications were performed in an automated thermal cycle (model Techno 512) programmed for one cycle at $94^{\circ} \mathrm{C}$ for 4 min followed by 45 cycles of $1 \mathrm{~min}$ at $94^{\circ} \mathrm{C}, 1 \mathrm{~min}$ at $57^{\circ} \mathrm{C}$, and $2 \mathrm{~min}$ at $37^{\circ} \mathrm{C}$. the reaction was finally stored at $72^{\circ} \mathrm{C}$ for $10 \mathrm{~min}$.

Table 1. List of the primer names and their nucleotide sequences used in the study for RAPD procedure

\begin{tabular}{lcc}
\hline & Name & Sequence \\
\hline $\mathbf{1}$ & OP-A2 & $5^{\prime}$ GTG ATC GCA G3 \\
$\mathbf{2}$ & OP-A07 & $5^{\prime}$ GAA AGG GGT G 3 \\
$\mathbf{3}$ & OP- B9 & $5^{\prime}$ CTCACCGTCC 3` \\
4 & OP-C13 & $5^{\prime}$ GGACCCAACC 3` \\
$\mathbf{5}$ & OP-D1 & $5^{\prime}$ ACC GCG AAG G 3 \\
\hline
\end{tabular}

Table 2. List of the primer names and their nucleotide sequences used in the study for ISSR procedure

\begin{tabular}{|c|c|c|}
\hline No & Name & Sequence \\
\hline 1 & $14 \mathrm{~A}$ & 5 СТC ТCT СТC ТCT СТC TTG 3` \\
\hline 2 & HB-8 & $5^{\prime}$ GAG AGA GAG AGA GG $3^{`}$ \\
\hline 3 & HB-12 & $5 \mathrm{CAC}$ CAC CAC GC 3 \\
\hline 4 & HB-14 & $5^{\prime}$ CTC CTC CTC GC 3` \\
\hline 5 & HB-15 & $5^{\prime}$ GTG GTG GTG GC $3^{\prime}$ \\
\hline
\end{tabular}

Gel preparation procedure

1- Agarose (1.50 gm) was mixed with (100ml) $1 \mathrm{x}$ TBE buffer and boiled in microwave.

2- Ethidium bromide $(5 \mu \mathrm{l})$ was added to the melted gel after the temperature became $55^{\circ} \mathrm{C}$.

3- The melted gel were poured in the tray of minigel apparatus and comb was inserted immediately, then comb was removed when the gel become hardened.

4- The gel was covered by the electrophoretic buffer (1 x TBE).

5- DNA amplified product $(15 \mu \mathrm{l})$ was loaded in each well

6- DNA ladder (100bp) mix was used as standard

DNA with molecular weights of 3000 , 1500,1000,900, 800, 700,600, 500, 400, 300, 200 and $100 \mathrm{bp}$. The run was performed for about 30 min at $80 \mathrm{~V}$ in mini submarine gel BioRad .

\section{Data analysis}

All date obtained during both 2018 \& 2019 experimental seasons were subjected to analysis of variance and significant as factorial experiments in completely randomize blokes difference among means were determined according to (Snedecor and Cochran, 1980). In addition, significant difference among means were distinguished according to the Duncans multiple test range (Duncan, 1955) using letters for differentiating the values of each investigated measurement.

The similarity matrices were done using Gel works ID advanced software UVP-England Program. The relationships among genotypes as revealed by dendrograms were done using SPSS windows (Version 10) program. DICE computer package was used to calculate the pairwise difference matrix and plot the phenogram among strains (Yang and Quiros, 1993).

\section{Results and Discussion}

1. Biochemical genetic evaluation using SDS-Protein and isozymes electrophoresis banding patterns:

\section{A. SDS-Protein electrophoresis.}

Leaf protein electrophoresis provides valuable evidence for taxonomic and evolutionary relationships of plant species. It is worthy to note that leaf protein profiles are often species - specific, highly stable and unlikely to be not influenced by environmental conditions and seasonal fluctuations (Yates et al., 1990).

The electrophoretic banding pattern of protein extracted from leaves of Psidium guajava genotypes are shown in Figure 1. Results of leaves SDS-PAGE revealed a total number of 16 bands with molecular weight (MW) ranging from about 3.6 to $192 \mathrm{KDa}$. Analysis of data showed eight common bands (monomorphic bands) while, the remaining eight bands were polymorphic with $50 \%$ polymorphism. On the other hand, there were three unique bands two of them were negative unique bands: the first with genotype 1 at $192 \mathrm{KDa}$ and the second was with genotype 12 at $68 \mathrm{KDa}$ and the last one was positive unique bands with genotypes 12 at $112 \mathrm{KDa}$. 


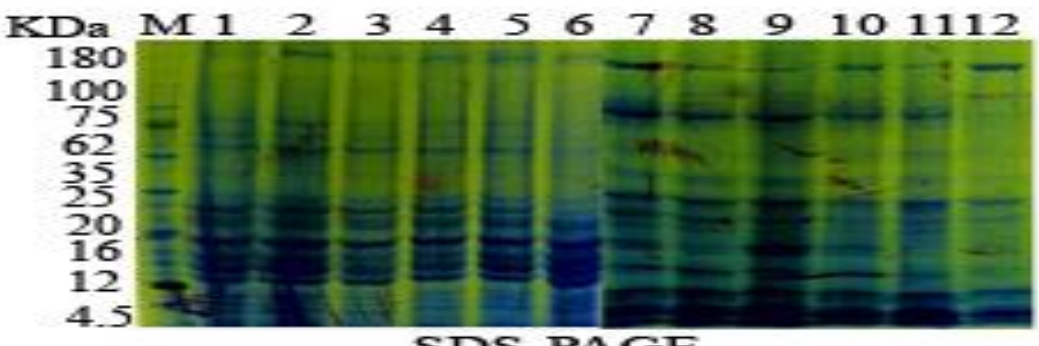

SDS-PAGE

Figure 1: SDS- leaf protein banding patterns of the twelve guava seedling trees

1.B. Peroxidase electrophoresis banding patterns:

Figure 2 illustrated leaf peroxidase electrophoresis banding patterns of the twelve Psidium guajava genotypes. A total of four bands were characterized for the studied 12 guava seedling trees which three of them (monomorphic) were represented in all 12 guava seedling trees with differences in their banding patterns densities and they could be considered as common bands. The remaining band (polymorphic) was absent in only one strain 4 with relative mobility 0.6 and present in the other genotypes.

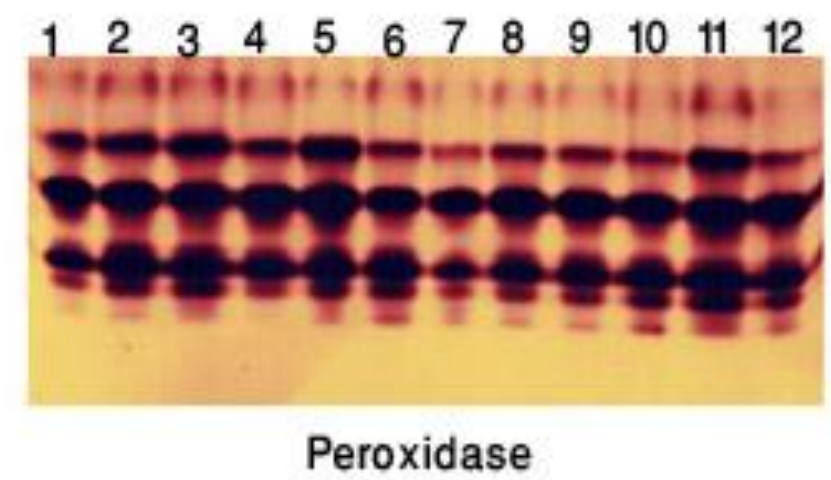

Figure 2: Leaf peroxidase isozyme banding patterns of the twelve guava seedling trees.

\section{C. Polyphenyl oxidase electrophoresis banding} patterns:

Figure 3 demonstrated Poly Phenyl Oxidase (PPO) banding patterns among examined leaves of the twelve Psidium guava genotypes. Obtained patterns exhibited four bands with relative mobiliteis 0.25 , $0.35,0,50$ and 0.60 all of them were present in all 12 trees (monomorphic) with differences in banding patterns density which could be considered as common band for all the twelve guava seedling trees.

These techniques could detect enough polymorphism in the Psidium guava genotypes to distinguish each genotype from the others by at least band or group of combined banding pattern. Furthermore, the use of these data in the future is important for Psidium guajava germplasm management, improvement as well as for the selection strategies of parental lines that facilitate the prediction of crosses in order to produce hybrids with higher performance (Mansoor et al., 1998; 1999 and Hassan et al., 1998).

Several isozymes have been found to detect useful amounts of variation in species. Isozymes analysis has also revealed some cases of obvious mislabelling of plant material. The differences between electrophoretic patterns could be observed with simple visual analysis, but the smaller differences were revealed only by densitometer analysis. The method of biochemical markers allow to solve whole number of problems for selection such as identification of genotypes, analysis of hybrids, selection of valuable genotype. The most investigations of enzyme polymorphism for fruits were carried out for evaluation of genotypes.(Biruk and Kazlovskaya,2008). 


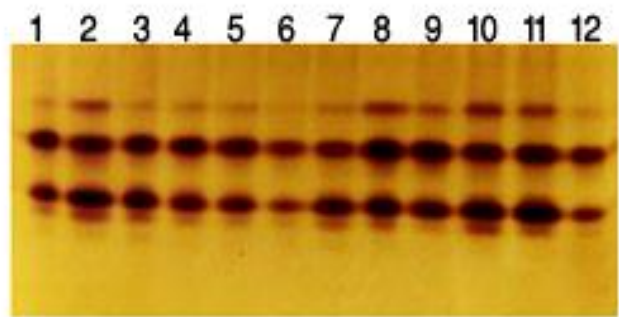

\section{Polyphenyl Oxidase}

Figure 3: Leaf polyphenyl oxidase isozyme banding patterns of the twelve genotypes of Psidium guajava

2. Molecular genetic diversity or similarity of the 12 selected guava seedling trees based on RAPD and ISSR:

2. A. Molecular genetic similarity of Psidium guajava genotypes based on RAPD:

Initially, the application of molecular marker techniques was hampered by the difficulty in extracting genomic DNA from mucilaginous tissues
(Griffith and Porter, 2003). However, researchers have demonstrated that RAPD patterns can be obtained from cacti using primers OPA-11 (De La Cruz et al., 1997), and OPA-12 (Tel-Zur et al., 1999). RAPD profiles have been used to verify the maternal origin of apomictic seedlings in cactus pear (Mondragón, 2002). 


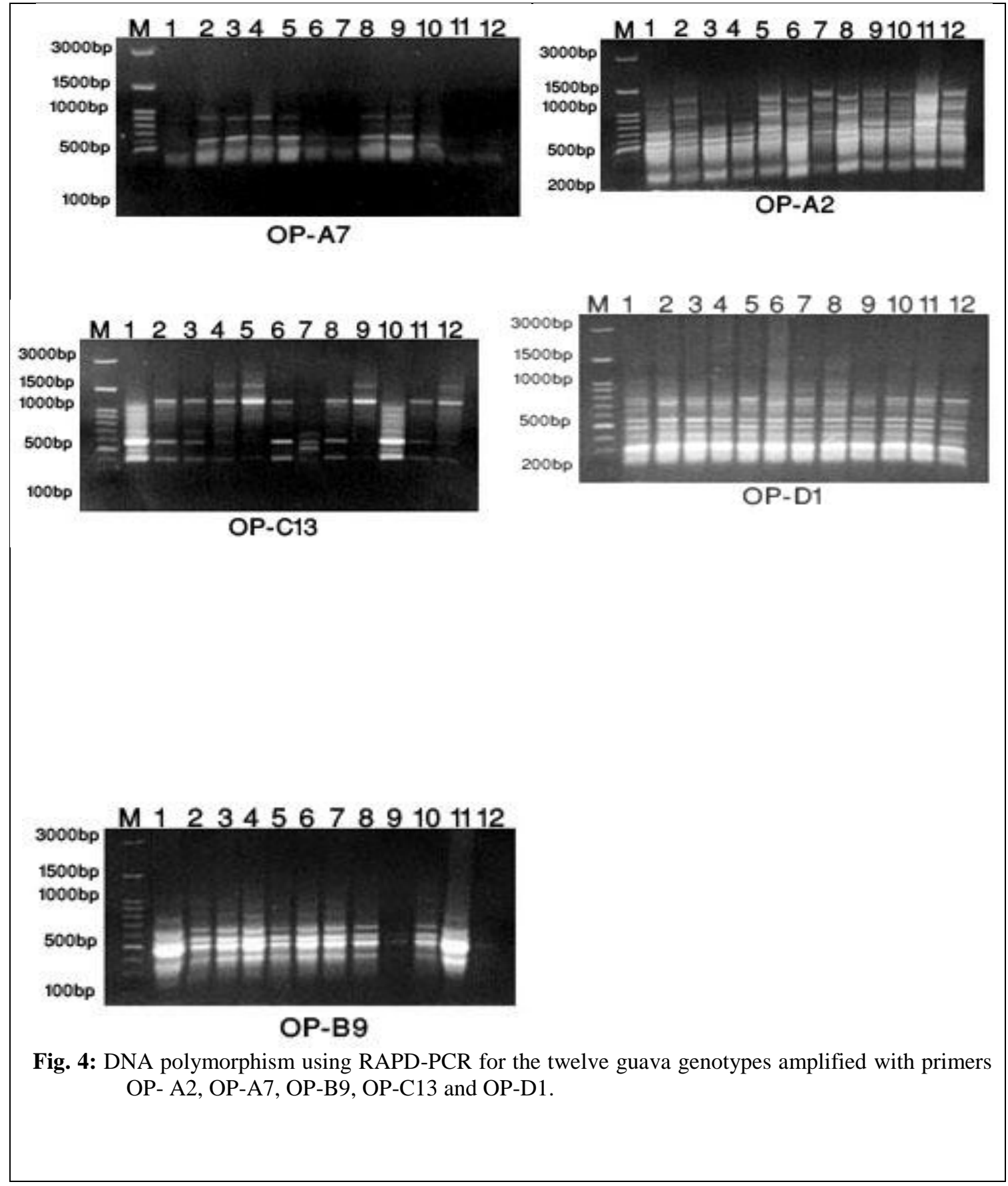

Table 3. List of RAPD primers of twelve genotypes of Psidium guajava. Percentage of polymorphism and Unique bands (SM)

\begin{tabular}{ccccccc}
\hline & Sequence & \multirow{2}{*}{ Total Band } & $\begin{array}{c}\text { Monomorphic } \\
\text { Band }\end{array}$ & $\begin{array}{c}\text { Polymorphic } \\
\text { Band }\end{array}$ & $\begin{array}{c}\text { Unique } \\
\text { band }\end{array}$ & $\begin{array}{c}\text { Polymorphic } \\
\%\end{array}$ \\
\hline OP-A2 & 5' GTG ATC GCA G3 $^{\prime}$ & 14 & 8 & 6 & 3 & $42.58 \%$ \\
OP-A7 & 5 GAA AGG GGT G 3 $^{\prime}$ & 7 & 2 & 5 & 1 & $71.42 \%$ \\
OP-B9 & 5 CTCACCGTCC 3 & 10 & 3 & 7 & - & $70.00 \%$ \\
OP-C13 & 5 GGACCCAACC 3 & 11 & 5 & 6 & - & $54.56 \%$ \\
OP-D1 & $5^{\prime}$ ACC GCG AAG G 3 & 9 & 5 & 4 & 1 & $44,44 \%$ \\
\hline Total & & $\mathbf{5 1}$ & $\mathbf{2 3}$ & $\mathbf{2 8}$ & $\mathbf{5}$ & $\mathbf{5 4 . 9 0 \%}$ \\
\hline
\end{tabular}


-Genetic relationship between twelve Psidium guajava genotypes based on RAPD analysis.

The similarity between the twelve selected seedling trees of Psidium guajava ranged from 0.07 to 1.00 and the highest similarity was between genotypes 1 and 10 at 1.00 and the lowest similarity was between genotypes 3 and 4. UPGMA cluster and analysis based on genetic similarity values for RAPD markers from all the Psidium guajava genotypes was used to construct classify twelve genotypes of Psidium guava
Table 13 and Figure 6. Results from this analysis showed two main groups. The first main group was genotype 1 alone and the second main group was divided into two sub main groups: the first sub main group included genotypes 9 and 12 and the second sub main group was divided into two sub sub group: the first sub sub group was included genotypes 10 and 11 , and the second sub sub group was included other seven genotypes $2,5,4,3,8,7$ and 6 .
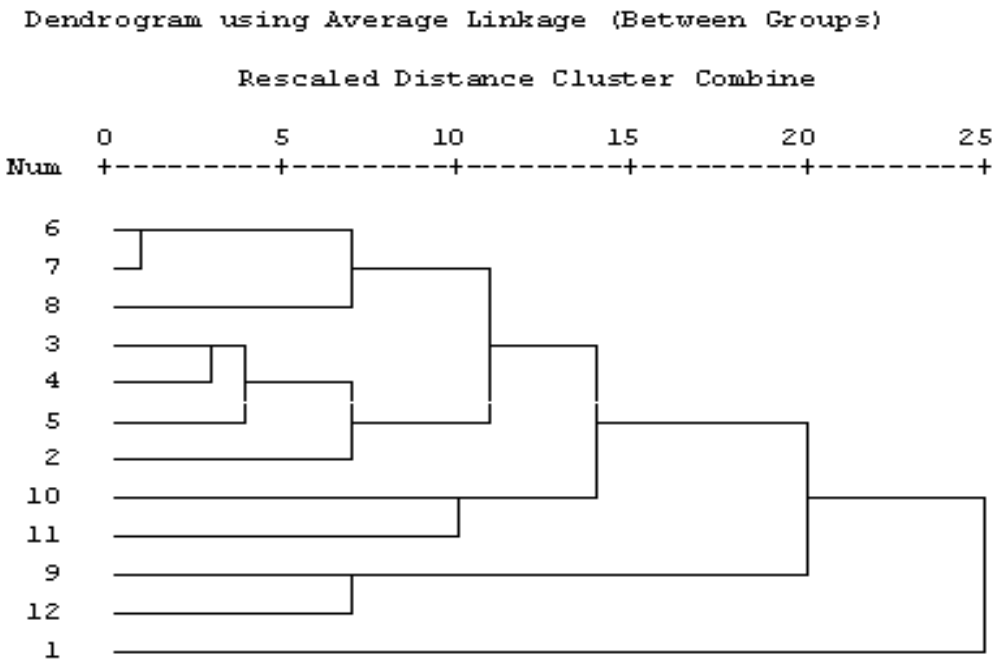

Fig.5: Unweighted pair group method with arithmetic mean (UPGMA) dendrogram illustrating the genetic relationships between twelve Psidium guajava genotypes based on RAPD analysis

\section{B. Molecular genetic evaluation of Pisidium guava genotypes based on ISSR:}

Besides the use of ISSR markers in micro evolutionary studies, this technique has also been used in the estimation of genetic diversity and differentiation among individuals and closely related plant species ( Rana et al., 2012). For instance, Luna-
Paez et al., (2007) employed this technique for variety distinction, whereas Alves et al., (2009) used it to develop strain-unique bands. This PCR-based technique generates multilocus highly polymorphic dominant genomic markers without the need of prior DNA sequence knowledge (Mishra et al., 2003). 


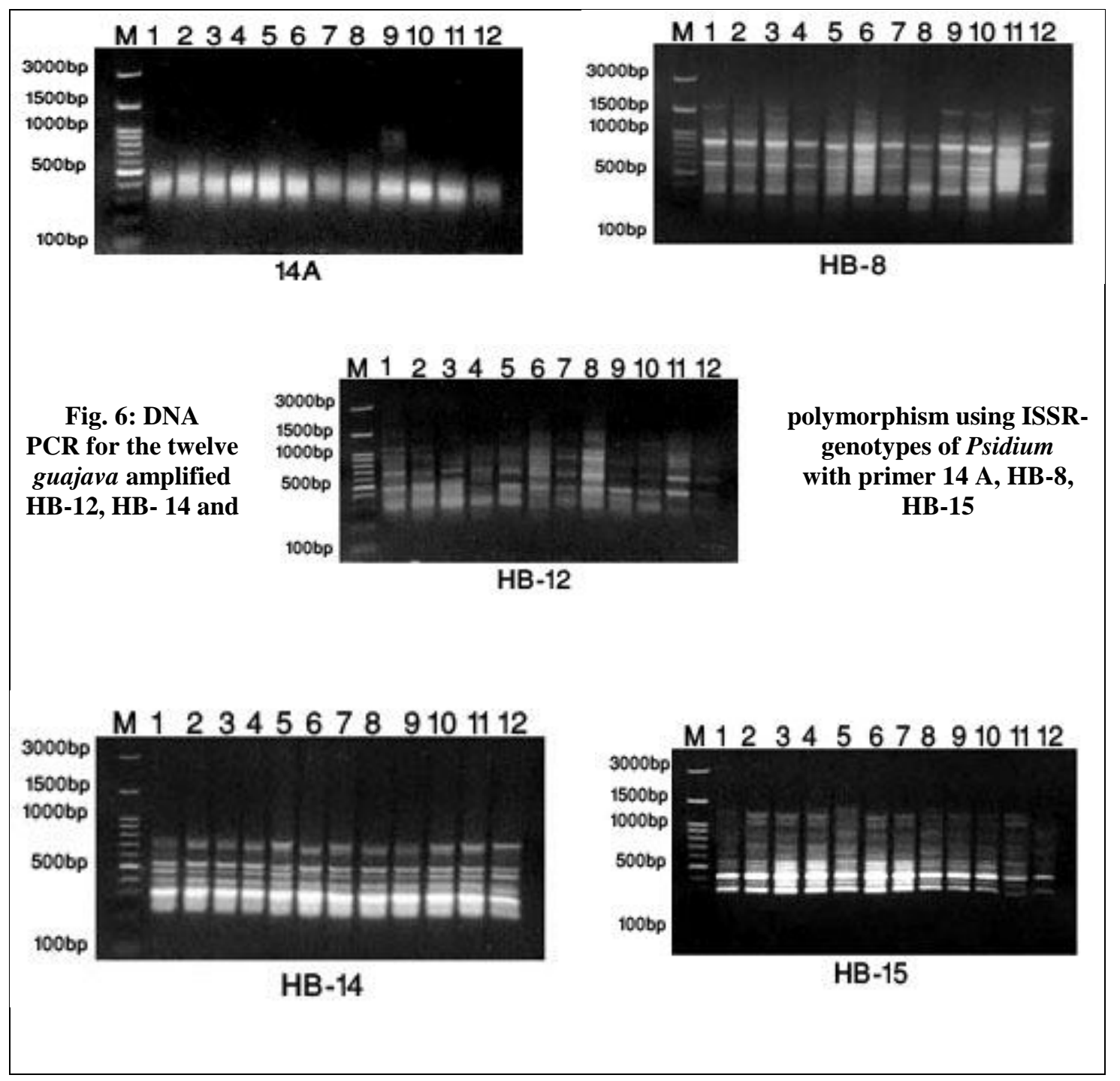

Table 4. List of ISSR primers of twelve genotypes of Psidium guajava Percentage of polymorphism and Unique bands (SM)

\begin{tabular}{ccccccc}
\hline $\begin{array}{c}\text { Primer } \\
\text { Name }\end{array}$ & Sequence & $\begin{array}{c}\text { Total } \\
\text { Band }\end{array}$ & $\begin{array}{c}\text { Monomorphic } \\
\text { Band }\end{array}$ & $\begin{array}{c}\text { Polymorphic } \\
\text { Band }\end{array}$ & $\begin{array}{c}\text { Unique } \\
\text { Band }\end{array}$ & $\begin{array}{c}\text { Polymorphic } \\
\%\end{array}$ \\
\hline 14A & 5 CTC TCT CTC TCT CTC TTG 3 & 4 & 3 & 1 & - & $25.00 \%$ \\
HB-8 & 5' GAG AGA GAG AGA GG & 11 & 5 & 6 & 2 & $54.54 \%$ \\
HB-12 & 5 5 CAC CAC CAC GC 3` & 12 & 3 & 9 & 2 & $75.00 \%$ \\
HB-14 & 5' CTC CTC CTC GC 3 & 7 & 6 & 1 & - & $14.28 \%$ \\
HB-15 & 5' GTG GTG GTG GC 3` & 9 & 6 & 3 & 2 & $33.33 \%$ \\
\hline Total & & 43 & 23 & 20 & 7 & $46.51 \%$ \\
\hline
\end{tabular}

A total number of 43 bands were produced from ISSR analysis and visualized across the investigated twelve genotypes of Psidium guajava, the results obtained 43 total bands with molecular weight from 235 to $2240 \mathrm{bp}, 20$ of total amplified bands were polymorphic $(46.51 \%)$ and the highest polymorphic percentage was $75 \%$ produced with primer HB-12 and the lowest polymorphic percentage was $14.28 \%$ produced with primer HB-14. On the other hand, total of 23 monomorphic bands were appeared and seven unique bands in five primers. Finally, primer HB-12 was the highest amplified bands (12 bands) whereas, primer 14-A were lowest amplified bands (4bands).Two genotypes-unique bands were detected among the polymorphic bands obtained with primer HB-78; one as a positive marker for genotype 8 at $1305 \mathrm{bp}$ also, the other one as negative marker for genotype 7 at 630bp. Two genotypes -unique bands were found, among the polymorphic bunds obtained with primer HB-12 one of them was positive markers 
with genotype 8 at $2240 \mathrm{bp}$ and the other was detected as negative marker with genotype 9 at 525bp. In addition two genotypes-unique bunds were also obtained by the HB-15 primer one as positive marker for genotype 5 at $1365 \mathrm{bp}$, but second as negative for genotype 1 at $685 \mathrm{bp}$.

On the other hand, no genotype unique (SM) bunds were obtained by the two other ISSR primers i.e., (14-A and HB-14).

Similar results were reported in castor (Gajer et al., 2010). However, both of the markers worked effectively in the assessment of genetic diversity in canola as they exhibited more than $60 \%$ polymorphism. Knowledge of genetic similarity (distance) between genotypes and among individuals or populations is useful in a breeding program because it permits organization of germplasm and provides more efficient sampling of genotypes to cross for the development of populations (Afiah et al., 2007).
-Genetic relationship between Psidium guajava genotypes based on ISSR analysis.

The similarity between the twelve genotypes of Psidium guajava ranged from 0.07 to 1.00 and the highest similarity was between genotypes 2 and 9 at 1.00 and the lowest similarity was between genotypes 3 and 4. UPGMA cluster and analysis based on genetic similarity values for RAPD markers from all the Psidium guajava genotypes was used to construct classify twelve genotypes of Psidium guajava (Fig.7 ). Results from this analysis showed two main groups. The first main group was between genotypes 9 and 12 and the second main group was divided into two sub main groups: the first sub main group included genotype 5 alone and the second sub main group was divided into two sub sub group: the first sub sub group was included genotype 6 alone and the second sub sub group was included other genotypes $1,11,8,7,2$, 3,10 and 4 .

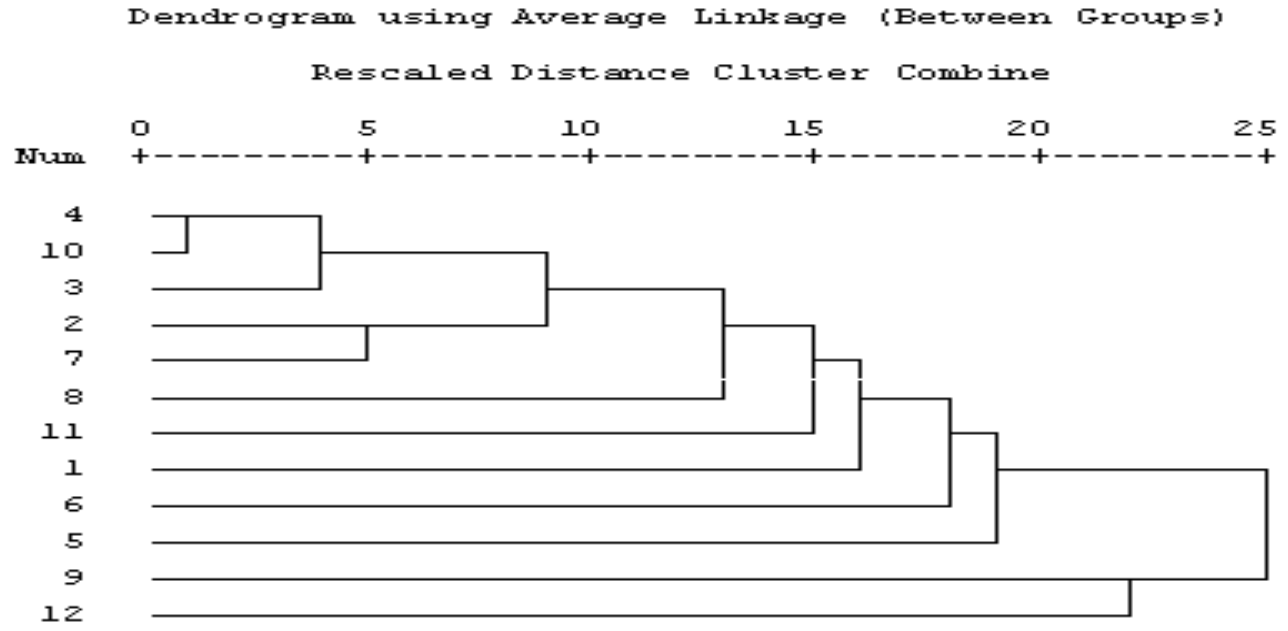

Fig. 7: Unweighted pairs group method with arithmetic mean (UPGMA) dendrogram illustrating the genetic relationship between twelve Psidium guajava genotypes based on ISSR analysis

ISSRs have been successfully used to estimate the extent of genetic diversity in a wide range of crop species which include sugarcane (Srivastava and Gupta, 2008 and Da Costa et al., 2011). In addition to that advantages (inexpensive, easy to generate), FISSR markers are more powerful and efficient in detecting polymorphisms within and among populations and/or species. The present study also utilized the F-ISSR markers previously used to investigate genetic diversity and relationships within and among the nineteen groups of sugarcane varieties of India. Molecular marker-based analysis of genetic diversity in plant species have become an important tool in crop improvement and conservation purpose (Weising et al., 2005).
2. C. Molecular genetic similarity of Pisidium guava genotypes based on combining between RAPD and ISSR

Table 5 investigated twelve genotypes of Psidium guajava, across five primers of RAPD and five primers of ISSR, the results obtained 94 total bands with molecular weight from 190 to 2240 bp, 48 of total amplified bands were polymorphic $51.06 \%$ and the highest polymorphic percentage was $54.90 \%$ produced with RAPD primers and the lowest polymorphic percentage was $46.51 \% \%$ produced with ISSR primers. On the other hand, total of 46 monomorphic bands were appeared and twelve unique bands in ten primers. 
Table 5. List of RAPD and ISSR primers of twelve genotypes of Psidium guajava. Percentage of polymorphism and Unique bands (SM)

\begin{tabular}{cccccc}
\hline $\begin{array}{c}\text { Primer } \\
\text { Name }\end{array}$ & $\begin{array}{c}\text { Total } \\
\text { band }\end{array}$ & Monomorphic band & $\begin{array}{c}\text { Polymorphic } \\
\text { band }\end{array}$ & Unique Band & Polymorphic \% \\
\hline RAPD & 51 & 23 & 28 & 5 & $54.90 \%$ \\
ISSR & 43 & 23 & 20 & 7 & $46.51 \%$ \\
Total & 94 & 46 & 48 & 12 & $51.06 \%$ \\
\hline
\end{tabular}

Genetic relationship between Psidium guajava genotypes based on combining RAPD and ISSR analysis.

By combining RAPD and ISSR, the similarity between the twelve genotypes of Psidium guajava ranged from 0.06 to 1.00 and the highest similarity was between genotypes 1 and 9 at 1.00 and the lowest similarity was between genotypes 3 and 4 (Table, 6). UPGMA cluster and analysis based on genetic similarity values for combining RAPD and ISSR markers from all the Psidium guajava genotypes was used to construct classify twelve genotypes of Psidium guajava (Fig. 8). Results from this analysis showed two main groups. The first main group was between genotypes 9 and 12 and the second main group was divided into two sub main groups: the first sub main group included strain 1 alone and the second sub main group was divided into two sub group: the first sub sub group was included two genotypes 10 and 11 and the second sub sub-group was included other genotypes 8 , $7,6,2,5,4$, and 3 .

Table 6. Similarity coefficient between twelve genotypes of Psidium guajava genotypes based on combining RAPD and ISSR analysis

\begin{tabular}{lllllllllllll}
\hline & 1 & 2 & 3 & 4 & 5 & 6 & 7 & 8 & 9 & 10 & 11 & 12 \\
\hline 1 & 1 & & & & & & & & & & & \\
2 & 0.44 & 1 & & & & & & & & & & \\
3 & 0.60 & 0.23 & 1 & & & & & & & & & \\
4 & 0.58 & 0.22 & 0.06 & 1 & & & & & & & & \\
5 & 0.69 & 0.26 & 0.13 & 0.20 & 1 & & & & & & & \\
6 & 0.73 & 0.46 & 0.25 & 0.24 & 0.58 & 1 & & & & & & \\
7 & 0.82 & 0.30 & 0.16 & 0.32 & 0.44 & 0.25 & 1 & & & & & \\
8 & 0.73 & 0.46 & 0.17 & 0.24 & 0.42 & 0.25 & 0.33 & 1 & & & & \\
9 & 1.00 & 0.96 & 0.49 & 0.55 & 0.60 & 0.71 & 0.80 & 0.57 & 1 & & \\
10 & 0.49 & 0.50 & 0.37 & 0.21 & 0.40 & 0.37 & 0.30 & 0.37 & 0.53 & 1 & & \\
11 & 0.70 & 0.43 & 0.30 & 0.29 & 0.48 & 0.37 & 0.53 & 0.45 & 0.75 & 0.27 & 1 & \\
12 & 0.84 & 0.94 & 0.59 & 0.85 & 0.62 & 0.67 & 0.83 & 0.81 & 0.38 & 0.55 & 0.58 & 1 \\
\hline
\end{tabular}

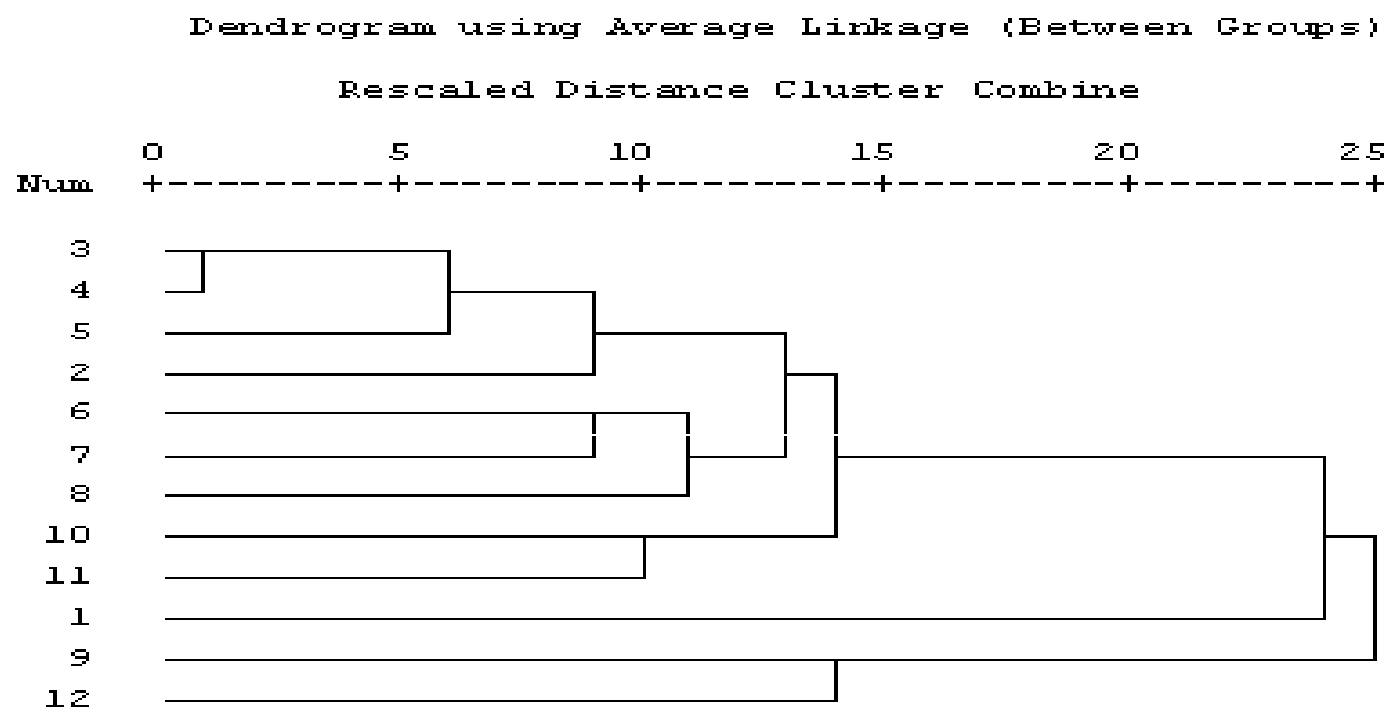

Fig.8: Unweighted pair group method with arithmetic mean (UPGMA) dendrogram illustrating the genetic relationships between twelve genotypes of Psidium guava based on combining RAPD and ISSR analysis. 
In this study, RAPD and ISSR markers based on the polymerase chain reaction (PCR) were applied. The value of RAPD analysis for efficient germplasm management in plants is already known (Young, 2000). The technique is quick, easy and required less time. This detects nucleotide sequence polymorphisms using a single primer of arbitrary nucleotide sequence (Williams et al., 1993). ISSR or microsatellite are currently becoming the preferred technique for the molecular characterization of different plant species because of higher repeatability, codominant nature, specificity and having multiple alleles (Plieske and Struss, 2001). ISSRs are based on tandem repeats of short (2 to 6 bp) DNA fragments scattered throughout the genome that lie between conserved sequences. It permits detection of polymorphisms in inter-microsatellite loci, using a primer designed from dinucleotide or trinucleotide simple sequence repeats.

\section{References}

Afiah, S. A.; Abdelsalam, A. Z.; Kamel, E. A.; Dowidar, A. E. and Ahmed, S. M. (2007): Molecular genetic studies on (Canola crosses) under Maryout conditions. African Crop Science Conference Proceedings, 8: 633-642.

Alves, R. R.; Nivaldo, N.; Léo Neto, A.; Gindomar, I.; Santana, G.; Washington, L.; Vieira, S. and Waltécio, O. (2009): Reptiles used for medicinal and magic religious purposes in Brazil Applied Herpetology (6) 257-274.

Anonymous (2019): Ministry of agriculture and land reclamation, economic affairs sector, bulletin of the agricultural statistics.

Biruk, A. and Z. Kazlovskaya (2008). Prospects for using of isozyme markers in identification of apple cultivars. Scientific works of the lithuanian institute of horticulture and lithuanian university of Agriculture. Sodininkyste ir daržininkyste. 2008. 27(2): 359-364

Boora, R. S. (2012): Improvement in guava (Psidium guajava L.) A review. Agric. Rev., 33(4):341-349.

Cabrita, L.; Elisiario, P.; Leitao, J.; Guerreiro, A.; Dore, C.; Dosba, F. and Baril, C. (2001): Assessment of the genetic relationships among Citrus species and varieties by isozyme and RAPD markers. Acta Horticulturae, 546: 177-181.

Chandler, W. H. (1958). Evergreen orchards. Henry kimpton, London, Pp. 452.

Coletta, H. D.; Machado, M. A.; Targon, M. L.; Moreira, M. C. and Pompeu, J. (2000): Analysis of phylogenetic diversity among mandarins (Citrus spp.) using RAPD markers. Euphytica, 102:133-139.

Cresti, M.; Linskens, H. F.; Mulcahy, D. L.; Bush, S.; Stilio, D. V.; Xu, M. Y.; Vignani, R. and Cimato, A. (1997): Preliminary communication about the identification of DNA in leaves and in olive oil of Olea europaea. Acta. Hort. 69: 36-37.
Da Costa, M. L.; Amorim, B. L.; Onofre, C. V.; DeMelo, T. O.; De-Oliveira, M. B.; De-Carvalho, R. and Benko-Iseppon, M. A. (2011): Assessment of genetic diversity in contrasting sugarcane varieties using Inter-Simple Sequence Repeat (ISSR) markers. American Journal of Plant Sciences 2:425-432.

De La Cruz, M.; Ramirez, F. and Hernandez, $H$. (1997): DNA isolation and amplification from Cacti Plant. Mol. Biol. Rep. 15, 319-325.

Gajer, B. B.; Kumar, N.; Singh, A. S.; Punvar, B. S.; Ravikiran, R.; Subhash, N. and Jadeja, G. C. (2010): Assessment of genetic diversity in castor (Ricinus communis L.) using RAPD and ISSR markers. Industrial Crops and Products, 32(3): 491-498.

Griffith, M. P. and Porter, J. M. (2003): Back to the basics: a simple method of DNA extraction for mucilaginous cacti. Bradleya, 21: 126- 128.

Hassan, H. Z.; Arfa, H. E. and Saeed, W. T. (1998): Biochemical and molecular genetic identification of some (Psidium guajava L.) cultivars. 3rd Arab Conference. Modern Biotech \& Areas of Application in the Arab world. Cairo, Egypt. Pp.67-87.

Laemli, U. K. (1970). Cleavage of structural proteins during the assembly of the head of bacteriophage T4. Nature, 227: 680-685.

Luna-Paez, A.; Valadez-Moctezuma, E., Barrientos-Priego, A. F.; Gallegos-Va'zquez, C. (2007): Characterization of Opuntia spp. by means of seed with RAPD and ISSR markers and its possible use for differentiation. J PACD 9:43-59

Mansoor, S.; Hussain, M.; Khan, S. H.; Bashir, A.; Leghari, A. B.; Panwar,G. A.; Siddiqui,W. A.; Zafar, Y. and Malik, K. A. (1998): Polymerase chain reaction-based detection of cotton leaf curl and other whitefly-transmitted Gemini viruses from Sindh Pak. J. Biol. Sci., 1 pp. 39-43.

Mansoor, S.; Bedford, I. D.; Pinner, M. S.; Stanley, J. and Markham, P. G. (1999): A whiteflytransmitted Gemini virus associated with cotton leaf curl disease in Pakistan Pak. J. Bot., 25 pp. 105-107.

Mishra, N.; Hazarika, N. C.; Narain, K. and Mahanta, J. (2003): Nutritive value of nonmulberry and mulberry silkworm pupae and consumption pattern in Assam, India. Nutr. Res., 23 (10): 1303-1311.

Mondragón, C. (2002): Caracterización genética de una colección de nopal (Opuntia spp.) de la región centro de México. Agricultura Técnica en México. pp. 3-14.

Plieske, J. and Struss, D. (2001): Microsatellite markers for genome analysis in Brassica. I. development in Brassica napus and abundance in Brassicaceae species Theor Appl Genet 102:689694. 
Popenoe, W. (1988): Manual of tropical and subtropical fruits. The Macmillan company, New York. Pp. 474.

Rana, T. S.; Narzary, D. and Ohri, D. (2012): Molecular differentiation of Chenopodium album complex and some related species using ISSR profiles and ITS sequences. Gene, 495:29-35

Srivastava, S. and Gupta, P. S. (2008). Inter Simple Sequence repeat profile as a genetic marker system in sugarcane. Sugar Tech 10:48-52.

Stegeman, J. J. (1985): Benzo[a]pyrene oxidation and microsomal enzyme activity in the mussel (Mytilus edu- lis) and other bivalve mollusc species from the Western North Atlantic. Mar. Biol. 89, 2130.

Tel-Zur, N.; Abbo, S.; Mylaboski, D. and Mizrahi, Y. (1999): Modified CTAB procedure for DNA isolation from epiphytic cacti of the genus Hylocereus and Selenicerus (Cactaceae). Plant Mol. Biol. Rep. 17, 249-254.

Tijet, N.; Waspi, U.; Gaskin, D. J.; Hunziker, P.; Muller, B. L.; Vulfson, E. N.; Slusarenko, A.; Brash, A. R. and Whitehead, I. M. (2000): Purification, molecular cloning and expression of the gene encoding fatty acid 13-hydroperoxide lyase from guava fruit (Psidium guajava L.). Lipids, 35: 709-720.

Weising, K., Nybom, H., Wolf, K. and Kahl, G. (2005). DNA fingerprinting in plants: Principles, Methods and Applications (2nd ed). CRC Press, Boca Raton, Florida, USA.

Yang, $X$ and. Quiros, C. F (1993). Identification and classification of celery strains with RAPD markers. Theoritical and Appleid Genetics, 86:205-212.

Yang, X.; Malik, M. N. and Quiros, C. F. (2000): Identification and classification of celery cultivars with RAPD markers. Theoritical and Appleid Genetics, 86:205-212.

Yates, M. G.; Ford, C. M.; Garg, N.; Garg, R. P.; Tibelius, K. H.; Arp, D. J. and Seefeldt, L. C. (1990): The identification, characterization, sequencing and mutagenesis of the genes (hupSL) encoding the small and large subunits of the H2uptake hydrogenase of (Azotobacter chroococcum). Molecular Microbiology, 4 (6), 999-1008

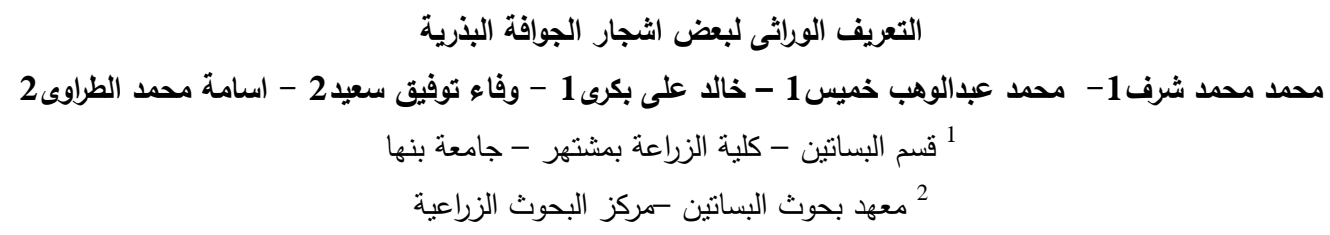

